\title{
LOCAL KNOWLEDGE OF EDIBLE GELAM MUSHROOM IN TERENGGANU
}

\author{
SHYEN YEE LEE AND AQILAH MOHAMMAD
}

Faculty of Science and Marine Environment, , Universiti Malaysia Terengganu, 21030 Kuala Nerus, Terengganu, Malaysia.

*Corresponding author: aqilahmohammad@umt.edu.my

Submitted: 5 September 2019 Accepted: 17 March 2020

http://doi.org/10.46754/jssm.2020.06.010

\begin{abstract}
The edible wild boletoid mushroom Tylopilus griseipurpureus, or locally known as gelam mushroom (as it is grows near gelam trees), has been uniquely consumed by local communities in Setiu and Besut in Terengganu, Malaysia. However, knowledge of this mushroom is poorly documented. Therefore, this study attempted to document the local knowledge on the consumption of T. griseipurpureus in two districts of the state. Members of selected local communities were interviewed to obtain information on the fungus' fruiting season, utilization and economic perspectives. T. griseipurpureus samples were also collected during its fruiting season. Overall, 38 respondents were interviewed, where women and the older generation were found to have better experience in handling the mushroom like collecting and cooking them. Majority of respondents said $T$. griseipurpureus fruiting bodies could be harvested between May and July, when heavy rain starts to fall after the hot season from the beginning of the year ends. The recipe of making kerabu kulat gelam and other ways of preparing dishes with this mushroom were recorded. The price of both fresh and boiled gelam mushrooms were also surveyed at local markets. The additional notes on the fruiting season, utilization and economical aspects of gelam mushroom in this study might provide better understanding on the ethnomycological aspects of the species.
\end{abstract}

Keywords: Ethnomycology, bolete, gelam mushroom, Tylopilus griseipurpureus, sustainability.

\section{Introduction}

Ethnomycology is the study of fungal utilization by humans or the relationship between traditional societies and fungi (Cardoso et al., 2010; Malaisse et al., 2012; Kik et al., 2013). The ethnomycological field also investigates the consumption of mushrooms by humans, focusing on their nutritional and medicinal aspects, as well as the ectomycorrhizal relationship and ecological benefits of macrofungi to the environment (Kinge et al., 2017). Ethnomycological knowledge also combines the biological resources, cultural and traditional practices of society that focus on the uses and essential roles of fungi in daily life (Foo et al., 2018).

The utilization of wild mushrooms has been widely studied in many countries, including India (Dutta \& Acharya, 2014; Kumar et al., 2017), China (Kang et al., 2016), Cameroon (Dijk et al., 2003; Yongabi et al., 2004; Kinge et al., 2017) and the Philippines (De Leon et al., 2013; Lazo et al., 2015). In Malaysia, wild mushrooms have been widely used as food by indigenous and local communities. They use it as soup flavouring (Chong et al., 2007) and it also improves the taste and texture of dishes (Chye et al., 2008).

This unique and excellent flavour, known as umami, is also called the "palatable taste" and is one of the five recognised tastes besides sweet, sour, salty and bitterness. Umami may stimulate appetite and is the taste receptors' response to glutamates, which are present in meat broths and fermented products. That taste may also be introduced into food by adding monosodium glutamate.

Mushrooms are suitable condiments for meat, seafood, stew, soup and vegetable dishes (Mau, 2005). People greatly appreciate them for their pleasant fruity aroma (Chye et al., 2008). Lee et al. (2009) documented the utilization of 
31 wild mushrooms as food and another 14 for medicinal purposes by indigenous communities in Peninsular Malaysia. In addition, Mohammad \& Hamzah (2015) recorded 10 macrofungal species that are utilized as food and medicine by the Bateq sub-tribe in Kampung Orang Asli Kuala Koh, Kelantan, in which the method of usage for each sample is detailed in their report. Meanwhile, Foo et al. (2018) reported 25 wild mushroom species as being edible and five that have potential medicinal uses by four ethnic communities in Sabah (Northern Borneo). Despite the ethnomycology studies that have been conducted in Malaysia (Chang \& Lee, 2004; Lee et al., 2009; Abdullah \& Rusea, 2009; Foo et al., 2018), it is still believed that the documentation on mushroom utilisation as food and medicine is still sparse and limited.

The boletoid fungi are members of the Boletaceae family under the phylum Basidiomycota in the Fungi kingdom (Eumycota). Fungi that belong to this group are associated with nearby tree roots and form mutual relationships with other plants known as mycorrhizae (Kuo, 2013). T. griseipurpureus has been identified as a bolete species found in Setiu and Besut districts of Terengganu (Lee, unpublished). It is widely collected by locals and made into delicacies during its annual fruiting season from May to July. The fungus is locally known as kulat gelam because it tends to grow near paperbark trees (pokok gelam) (Melaleuca cajuputi) in the sandy beach ridges (BRIS) of Kelantan and Terengganu (Figure 1) (Lee, unpublished).

Morphologically, this fungus is grey to violet white when young, and turns brown or reddishbrown with age. Its pileus (cap) is smooth and either convex or plane shaped, which sometimes may look powdery. The stipe (stalk) is either clavate or cylindrical, with reticulated patterns on the surface. The hymenophore of the gelam mushroom is made up of tubular pores, which is white when young and turns pale brown with age. In the forest area dominated by $M$. cajuputi, it can be found growing on soil near the trees, which is mostly covered with leaf litter (Figure 2).

T. griseipurpureus is reportedly a favourite edible wild mushroom found in Bachok, Kelantan, and South Thailand (Aung-audchariya et al., 2012; Angajchariya et al. 2017; Lau et al., 2017). Early studies have documented the mushrooms in Kelantan and Thailand as Boletus griseipurpureus. But later, the taxonomic name has been changed to $T$. griseipurpureus according to Index Fungorum (2020) and the Mycobank Database (2019).

To date, not much knowledge regarding this edible boletoid species in Malaysia has been documented. Thus, this study aims to document the local knowledge in utilizing and consuming

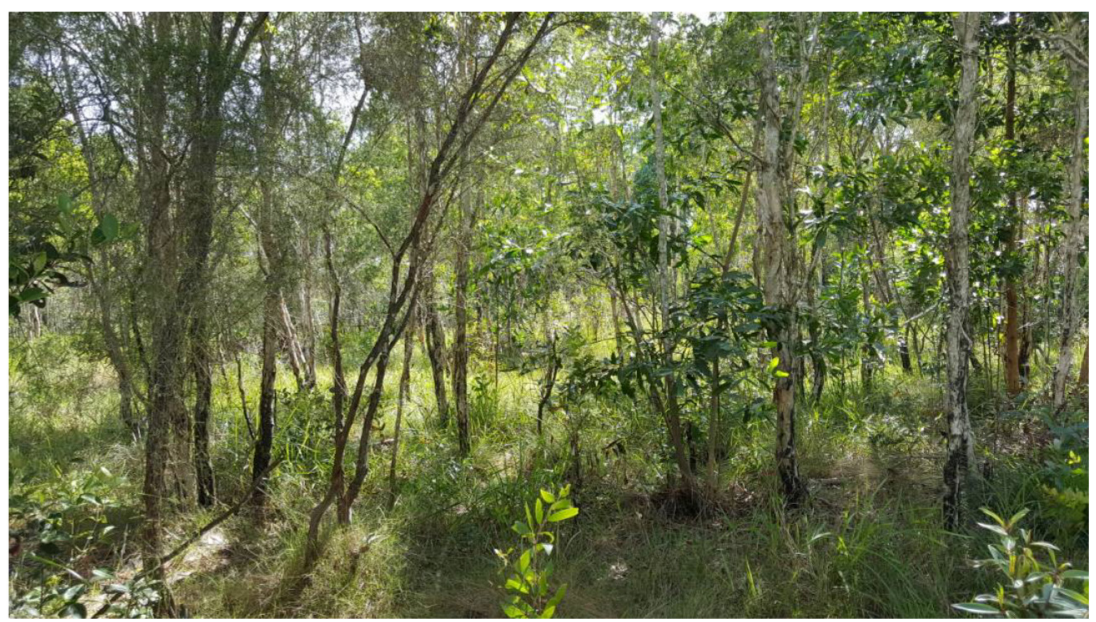

Figure 1: Paperbark trees (Melaleuca cajuputi) growing in a forest near a beach in Terengganu 


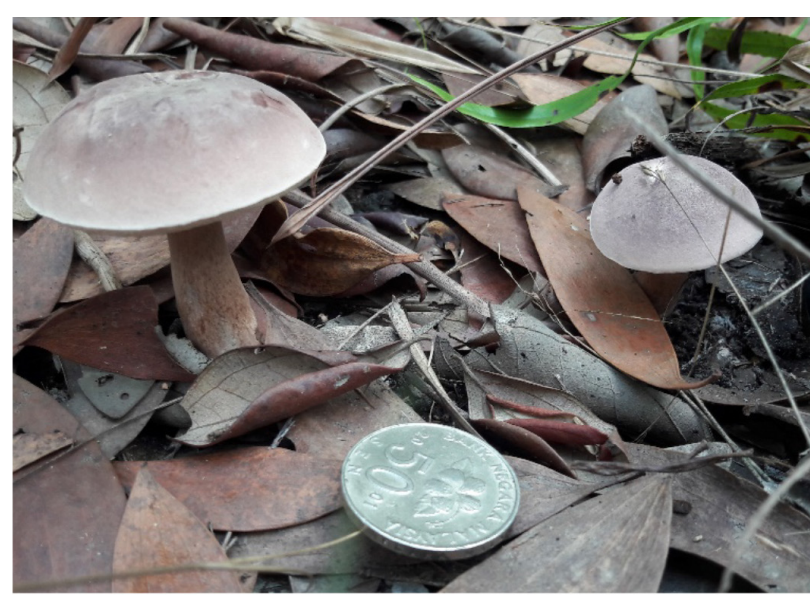

Figure 2: Mature gelam mushrooms found in its habitat

gelam mushrooms by local communities in Setiu and Besut districts of Terengganu.

\section{Materials and Methods}

\section{Study areas and sample collection}

The study was conducted in Setiu and Besut districts in Malaysia's northeastern state of Terengganu during the fruiting season from April to July 2019 (Figure 3). Local areas, such as Gong Batu, Pengkalan Gelap, Telaga Papan and Telaga Papan Baru, where the communities were known to be involved in gelam mushroom collection, were visited to conduct interviews and collect samples. Villagers were also roped in to help identify the morphology of
T. griseipurpureus growing in the wild and the location of paperbark tree forests where it was usually collected. Besides that, selected wet markets that sold $T$. griseipurpureus were also visited, namely the Kampung Mangkok market (5.605591 N, 102.816352 E) in Setiu district, and the Kuala Besut wholesale market (5.810880 N, 102.544103 E) and Besut farmers' market $(5.830194 \mathrm{~N}, 102.550114 \mathrm{E})$ in Besut district.

Each study area in Setiu and Besut were visited once every week during the study period, and mushrooms were collected particularly in Gong Batu, Pengkalan Gelap, Telaga Papan and Telaga Papan Baru with the help of local villagers.

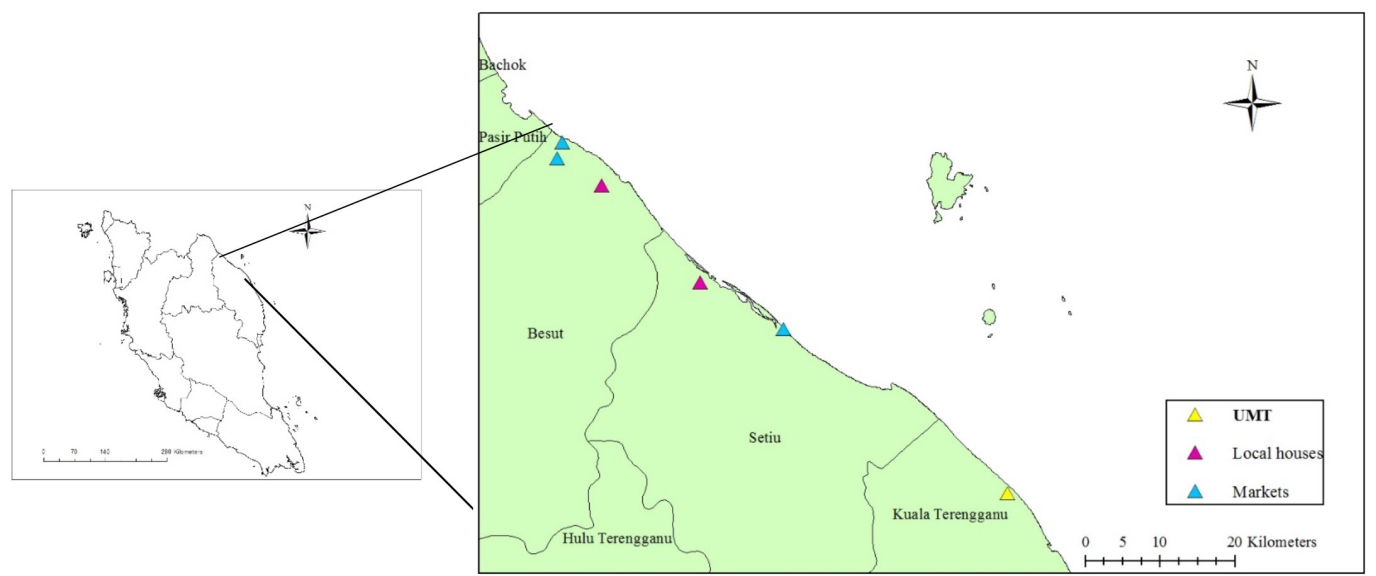

Figure 3: Location of markets and houses in Setiu and Besut districts of Terengganu visited for T. griseipurpureus sample collection 


\section{Sampling frame}

An ethnomycological survey was carried out through interviews. Snowball sampling was used to gather more respondents and a set of questions was prepared and presented before sample collections. The interview questions assessed the respondents' knowledge in identifying the mushroom's characteristics, its fruiting season, utilization and economic aspects.

The respondents were chosen based on their experience in collecting, buying and cooking the mushroom. Verbal consent was obtained to use and publish the information they provided (Figure 4). Greengrocers at selected wet markets and their customers were also interviewed (Figure 5). The demographic data of respondents were summarized and presented in graphs.

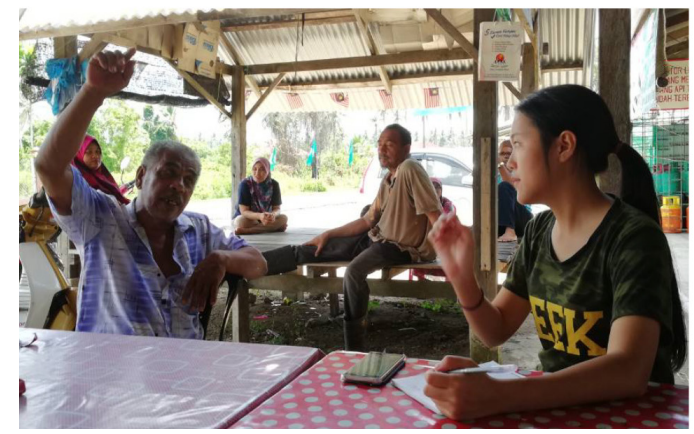

Figure 4: Interviewing a local resident on his knowledge in collecting and utilising $T$. griseipurpureus

\section{Results and Discussion}

\section{Demographic Profile}

A total of 38 respondents comprising 10 males and 28 females were interviewed, where 18 were from Setiu (five males, 13 females) and 20 were from Besut (five males, 15 females). The number of respondents according to gender is shown in Figure 6. Overall, there were more females interviewed $(74 \%)$ than males. Based on interviews with locals, both men and women were involved in the mushroom collection. However, women had more knowledge in utilising the mushrooms. According to Lee et al. (2009), women played a crucial role in orally passing the indigenous knowledge on the mushroom to the younger generation. Women also tended to be involved in every economic aspect, from mushroom collection to processing and selling, besides cooking them to feed their families (Garibay-Orijel et al., 2012).

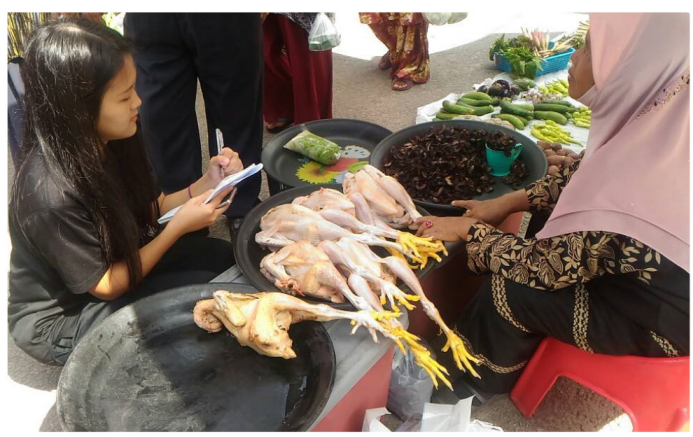

Figure 5: Interview with a greengrocer at a wet market

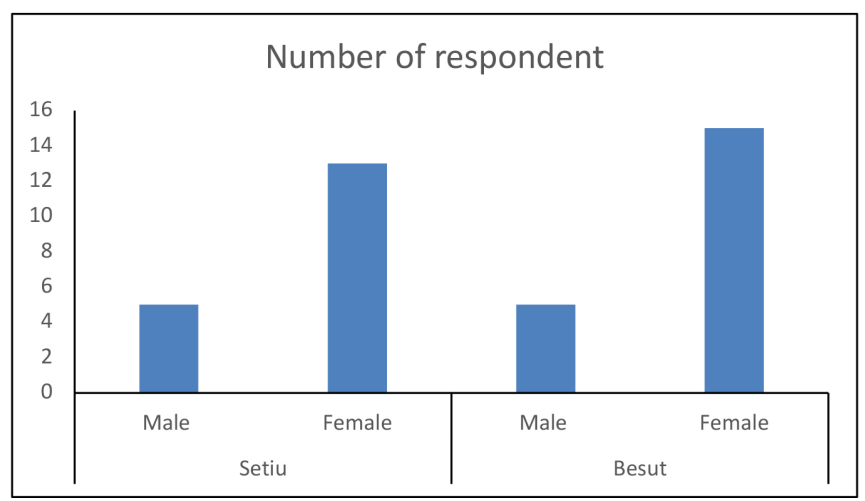

Figure 6: Number of respondents interviewed according to gender 


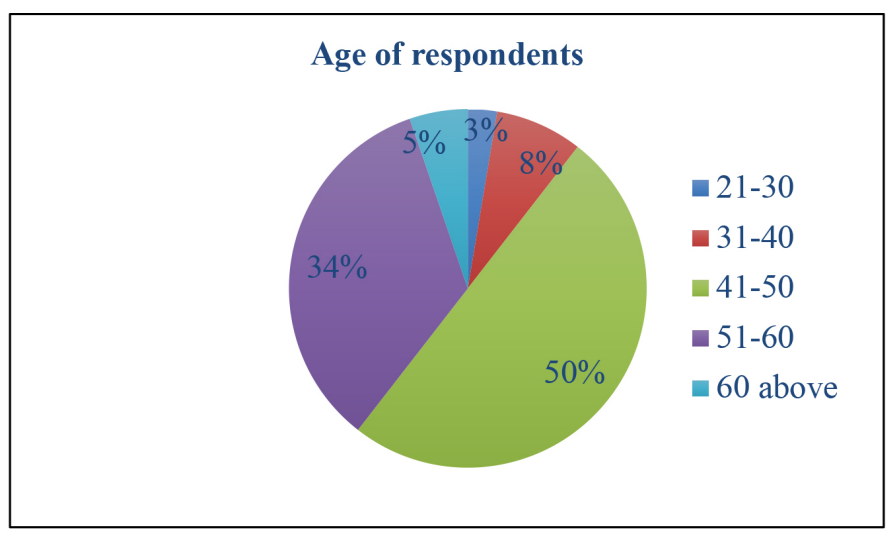

Figure 7: Percentage of respondents in different age groups (21-30 years old, 31-40 years old, 41-50 years old, 51-60 years old and above 60)

The age of respondents ranged from 21 to 70 , where the majority $50 \%$ were between age 41 and 50 . This was followed by those aged 51 to $60(34 \%)$ and other age groups (16\%). Although most respondents were middle-aged, the interviews suggested that the elderly tended to have prominent knowledge on utilization of the mushroom. Studies had shown that the older generation was very knowledgeable because they had more exposure and opportunities to utilise T. griseipurpureus in different ways throughout their lifetime (Lazo et al., 2015; Foo et al., 2018; Teke et al., 2018). The percentage of respondents in different age groups is shown in Figure 7. The younger generation tended to have little knowledge about the gelam mushroom's use compared to older generations. This was congruent with the study done by Lin (2005), which stated that the younger generation was more interested in migrating to cities to earn more income rather than learning about the mushroom trade. The urbanisation of local communities had also reduced the chances of retaining this traditional knowledge to pass down to future generations (Chang \& Lee, 2004; Lee et al., 2009).

\section{Local Knowledge on Mushroom Fruiting Season}

Local villagers would collect gelam mushrooms in forests dominated by paperbark trees. In the interviews, the respondents mostly emphasized the seasonal period as an indicator on when to collect the mushrooms. More than half of the respondents stated that a prolonged hot weather of several months, followed by heavy rainfall, would provide a conducive environment for the fruiting of this mushroom, and $34.2 \%$ of them said May to July was the peak fruiting season. However, they believed that the period could vary according to the weather.

The peak fruiting period of gelam mushrooms reported by Lau et al. (2017) in Kelantan differed slightly with this study, which was from June to September annually. Meanwhile, another recent study on gelam mushrooms in Besut reported that they could be found only in March or July, and in small quantities in December due to the rainy season and high humidity (Awang et al. 2018). Generally, according to Hussein et al. (2016), wild edible mushrooms were best collected during the rainy season. Temperature, rainfall and humidity levels were main factors that affected the fructification of mushrooms (Giri \& Rana, 2008).

\section{Local Knowledge on Mushroom Culinary (Thematic Analysis)}

All respondents said they consumed $T$. griseipurpureus as food. Mushrooms had been identified as a health food because of its high nutrient content (Cheung, 2010). The respondents consumed gelam mushrooms 
because they found it to be palatable. This study recorded several ways on how the respondents ate gelam mushrooms, particularly in making kerabu and by dipping it in sauces or other condiments.

\section{'Kerabu Kulat Gelam'}

The most popular dish that used gelam mushroom was kerabu, a local salad. All respondents said this was the most common way to consume the mushroom. A local recipe was obtained from one respondent in Setiu (Pok Rizam, personal communication). First, the mushrooms were cleaned and washed. The base was cut off before the mushrooms were sliced into smaller pieces. Then, they were boiled for about 15 to 20 minutes with a little bit of salt.

Other ingredients included fish, young mangoes, dried shrimps, chilies, ginger, onion, cashew nuts, chives, Vietnamese coriander, coconut milk and grated coconut. The amount of ingredients were prepared in rough proportions based on the number of servings, and could be adjusted according to preference.

The onions and ginger were cut and crushed into paste. Similarly, the fish, after being cleaned, boiled and de-boned, was pounded into paste. The sliced gelam mushrooms, mangoes, chilies, chives and Vietnamese coriander were placed in a big bowl with crushed cashew nuts, and mixed with a small amount of coconut milk and grated coconut. All ingredients were stirred evenly before being served with a bit of salt and sugar as seasoning.

\section{Dipping in Sauces}

The other way to consume gelam mushroom was by dipping it in sauces like air asam (a mixture of tamarind juice, tomatoes, onion and chilies), sambal belacan (a mixture of chili paste, blended onion and garlic with lime juice) or budu (a local fermented fish sauce). Locals preferred to consume this together with rice.

\section{Other Methods of Consumption}

A respondent from Setiu said she usually stirfried gelam mushrooms with cabbage, carrots and broccoli (Wee, personal communication). Another respondent from Besut preferred to boil the mushroom in soup with cauliflower, carrots and cabbage since he enjoyed the tinge of the mushroom's bitterness.

There were locals who believed that gelam mushroom could help keep diabetes in control (Pok $\mathrm{Ku}$ et al., personal communication). However, there were no respondents who were personally taking the mushroom for such purpose. They also said the mushroom was not suitable for people with high blood pressure as eating it with medicine could cause dizziness. Thus, further scientific research would be required to investigate the medicinal properties of gelam mushroom.

\section{Local Knowledge on the Mushroom Market}

T. griseipurpureus was widely collected by locals to sell to middlemen from the neighbouring state of Kelantan, while others were for home consumption. One respondent (Pok Din, personal communication) claimed that the recipe to prepare T. griseipurpureus originated from Kelantan. Therefore, Kelantanese people in Setiu and Besut tended to buy the mushroom when it was on season.

The fresh mushrooms cost around RM6 to RM8 per kilogram, while boiled mushrooms in packets found at local wet markets were priced between RM 3 and RM4. This provided an additional source of income to local communities (Yongabi et al., 2004; Lazo et al., 2015). More than 17 mushroom species were known to be cultivated in Malaysia, and the grey oyster mushroom had the best demand for household consumption (Haimid et al., 2013; Amin et al., 2014; Rosmiza et al., 2016). Compared to gelam mushrooms, grey oyster mushrooms had better value as its market price ranged between RM7 and RM10 per kilogram, while retail price could range from RM12 to RM15 per kilogram (Haimid et al., 2013). 


\section{Conclusion}

This study had documented local knowledge of gelam mushroom in terms of its growth, utilization, consumption and economic aspects. Further studies could be conducted to explore the biological activities of this edible bolete, such as its antimicrobial, antibacterial and anticancer properties. Studies could also focus on boosting the market value of T. griseipurpureus to bring it on a par with other mushrooms. Since the utilization of $T$. griseipurpureus was limited because it was only found in Melaleuca forests within the Beach Ridges Interspersed with Swales (BRIS) soil in the coasts of Terengganu and Kelantan, it is imperative to preserve the local knowledge and conserve the species.

\section{Acknowledgements}

The authors wish to thank the Education Ministry's Fundamental Research Grant Scheme (FRGS 2016) (Vot 59453) and Faculty of Science and Marine Environment, Universiti Malaysia Terengganu, for supporting this study. The authors also appreciate the commitment and help provided by local communities in Setiu and Besut.

\section{References}

Abdullah, F., \& Rusea, G. (2009). Documentation of inherited knowledge on wild edible fungi from Malaysia. Blumea, 54, 35-38.

Amin, M. Z. M., Harun, A., \& Wahad, M. A. M. A. (2014). Status and potential of mushroom industry in Malaysia. Economic and Technology Management Review, 9b, 103-111.

Awang, N. A., Ali, A. M., Abdulrahman, M. D., \& Mat, N. (2018). Edible bitter mushroom from Besut, Malaysia. Journal of Agrobiotechnology, 9(2), 70-79.

Ayodele, S. M., Akpaja, E. O., \& Adamu, Y. (2011). Some edible and medicinal mushrooms of Igala Land in Nigeria, their sociocultural and ethnomycological used. International Journal of Science and Nature, 2(3), 473-476.

Cardoso, D. B. O. S., Queiroz, L. P. D., Bandeira, F. P., \& Góes-Neto, A. (2010). Correlations between indigenous Brazilian folk classifications of fungi and their systematics. Journal of Ethnobiology, $30(2), 252-264$.

Chang, Y. S., \& Lee, S. S. (2004). Utilisation of macrofungi species in Malaysia. Fungal diversity, 15, 15-22.

Cheung, P. C. K. (2010). The nutritional and health benefits of mushrooms. Nutritional Bulletin, 35(4), 292-299.

Chong, K. S., Chye, F. Y., Lee, J, S., \& Atong, M. (2007). Nutritional properties of some edible wild mushrooms in Sabah. Journal of Applied Sciences, 7(15), 2216-2221.

Chye, F. Y., Wong, J. Y., \& Lee, J. S. (2008). Nutritional quality and antioxidant activity of selected edible wild mushrooms. Food Science and Technology International, 14(4), 375-384.

De Leon, A. M., Luangsa-ard, J. J. D., Karunarathna, S. C., Hyde, K. D., Reyes, R. G., \& De la Cruz, T. E. E. (2013). Species listing, distribution, and molecular identification of macrofungi in six Aeta tribal communities in Central Luzon, Philippines. Mycosphere, 4(3), 478-494.

Dijk, H. V., Onguene, N. A., \& Kuyper, T. W. (2003). Knowledge and utilization of edible mushrooms by local population's rain forest of South Cameroon. A Journal of the Human Environment, 32(1), 19-23.

Dutta, A. K., \& Acharya, K. (2014). Traditional and ethno-medicinal knowledge of mushrooms in West Bengal, India. Asian Journal of Pharmaceutical and Clinical Research, 7(4), 36-41.

Foo, S. F., Saikim, F. H., Kulip, J., \& Seelan, J. S. S. (2018). Distribution and ethnomycological knowledge of wild edible mushrooms in Sabah (Northern Borneo), 
Malaysia. Journal of Tropical Biology and Conservation, 15, 203-222.

Garibay-Orijel, R., Ramínez-Terrazo, A., \& Ordaz-Velázquez, M. (2012). Women care about local knowledge, experiences from ethnomycology. Journal of Ethnobiology and Ethnomedicine, 8(1), 25. https://doi. org/10.1186/1746-4269-8-25

Giri, A. \& Rana, P. (2008). Ethnomycological knowledge and nutritional analysis of some wild edible mushrooms of Sagarmatha National Park (SNP), Nepal. Journal of Natural History Museum, 23, 65-77.

Haimid, M. T., Rahim, H., \& Dardak, R. A. (2013). Understanding the mushroom industry and its marketing strategies for fresh produce in Malaysia. Economic and Technology Management Review, 8, 27-37.

Hamzah, N. (2017). Utilization of Wild Mushrooms for Food and Medicine by Indigenous Communities in Kelantan and Terengganu, (Master's Thesis). Universiti Malaysia Terengganu, Malaysia.

Hussein, J. M., Tibuhwa, D. D., Mshandete, A. M., \& Kivaisi, A. K. (2016). Successful domestication of Lentinus sajor-caju from an indigenous forest in Tanzania. Journal of Applied Biosciences, 108, 10507-10518.

Index Fungorum (2020). Species Fungorum. http://www.speciesfungorum.org/Names/ SynSpecies.asp?RecordID $=624089$.

Kang, J., Kang, Y., Ji, X., Guo, Q., Jacques, G., Pietras, M., Łuczaj, N., Li, D., \& Łuczaj, L. (2016). Wild food plants and fungi used in the mycophilous Tibetan community of Zhagana (Tewo County, Gansu, China). Journal of Ethnobiology and Ethnomedicine, 12, 21-34.

Kik, A., Jeyarathan, P., \& DeBritto, S. (2013). Ethnomylogical Documentation of Mushroom Diversity of Wopkola in Mul District of Western Highlands Province, Papua New Guinea and Investigation of Antimicrobial Properties of Selected Species. $7^{\text {th }}$ HUON Seminar Achieving
Vision 2050 through Higher Education, Research, Science \& Technology November 13th to $14^{\text {th }}$ 2013. Papua New Guinea University of Technology, Lae, Papua New Guinea.

Kinge, T. R., Apalah, N. A., Nji, T. M., Acha, A. N., \& Mih, A. M. (2017). Species richness and traditional knowledge of macrofungi (mushrooms) in the Awing Forest Reserve and Communities, northwest region, Cameroon. Journal of Mycology, 2017, 1-9. https://doi.org/10.1155/2017/2809239.

Kumar, M., Harsh, N. S. K., Prasad, R., \& Pandey, V. V. (2017). An ethnomycological survey of Jaunsar, Chakrata, Dehradun, India. Journal of Threatened Taxa, 9(9), 10717-10725.

Kuo, M. (2018). The boletes. http://www. mushroomexpert.com/boletes.html.

Lau, M. F., Tajuddin, R., Mohd, M. H., \& Zakaria, L. (2017). Identification and factors affecting in-vitro growth of an indigenous mushroom, Boletus sp. From Bachok, Kelantan, Malaysia. Pertanika Journal of Agricultural Science, 40(1), 53-72.

Lazo, C. R. M., Kalaw, S. P., \& De Leon, A. M. (2015). Ethnomycological survey of macrofungi utilized by Gaddang communities in Nueva Vizcaya, Philippines. Current Research in Environmental \& Applied Mycology, 5(3), 256-262.

Lee, S. (2019). Species Identification, Nutritional Properties and Ethno mycological Aspects of a Wild Edible Bolete Mushroom found in Gelam Forests in Terengganu. Master's thesis. Universiti Malaysia Terengganu, Malaysia

Lee, S. S., Chang, Y. S., \& Noraswati, M. N. R. (2009). Utilization of macrofungi by some indigenous communities for food and medicine in Peninsular Malaysia. Forest Ecology and Management, 257, 2062-2065.

Lee, S. Y. (n.d.). Biology, Nutritional Values and Local Knowledge of Gelam Mushroom 
in Terengganu. Master's thesis. Universiti Malaysia Terengganu, Malaysia.

Lin, K. W. (2005). Ethnobotanical study of medicinal plants used by the Jah Hut peoples in Malaysia. Indian Journal of Medical Sciences, 59(4), 156-161.

Malaisse, F., Claus, W., Drolkar, P., Lopsang, R., Wangdu, L., \& Mathieu, F. (2012). Ü Ethnomycology and ethnobotany (South Central Tibet). Diversity, with emphasis on two underrated targets: Plants used for dyeing and incense. Geo-Eco-Trop, 36, 185-199.

Mau, J. L. (2005). The umami taste of edible and medicinal mushrooms. International Journal of Medicinal Mushrooms, 7, 119125.

Mohammad, A., \& Hamzah, H. N. (2015). A preliminary study on wild mushrooms utilised for food and medicine by Bateq communities at Kuala Koh, Gua Musang, Kelantan. In Ismail Jusoh, Isa bin Ipor, Aida Shafreena Ahmad Puad \& Ruhana Hassan (Eds.), Proceedings of Regional Taxonomy and Ecology Conference. Universiti Malaysia Sarawak, Kota Samarahan, Sarawak, Malaysia. (pp. 111-119).

Mohammad, A., Yee, L. S., \& Kasran, A. K. (2019). Macrofungi of Tasik Kenyir. In Greater Kenyir Landscapes Springer, Cham. pp. 67-74.

Mycobank Database (2019). Boletus griseipurpureus. http://www.mycobank.
org/Biolomics.aspx?Table=Mycobank\&Re $\mathrm{c}=270921 \&$ Fields $=$ All .

Rosmiza, M. Z., Dvies, W. P., Rosniza, A. C. R., Jabil, M. J., \& Mazdi, M. (2016). Prospects for increasing commercial mushroom production in Malaysia: Challenge and opportunities. Mediterranean Journal of Social Sciences, 7(1S1), 406-415.

Salim, J. M., Mohamad, A., Taib, M., \& Aziz, N. A. (2011). Macrofungi of Jambu Bongkok Forest Reserve and nearby ecosystem. In A biological assessment of Jambu Bongkok Forest Reserve, Terengganu and nearby ecosystem (Eds.) . Publisher Universiti Malaysia Terengganu. (pp. 68-76).

Tantengco, O. A. G., \& Ragragio, E. M. (2018). Ethnomycological survey of macrofungi utilized by Ayta communities in Batan, Philippines. Current Research in Environmental \& Applied Mycology, 8(1), 104-108.

Teke, N. A., Kinge, T. R., Nji, T. M., Ndam, L. M., \& Mih, A. M. (2018). Ethnomycological study in the Kilum-Ijim mountain forest, Northwest Region, Cameroon. Journal of Ethnobiology and Ethnomedicine, 14(1), 25-36.

Yongabi, K., Agho, M., \& Martínez-Carrera, D. (2004). Ethnomycological studies on wild mushrooms in Cameroon, Central Africa. Micologia Aplicada International, 16(2), 34-36. 